\title{
Ptychoverpa bohemica (Pezizales) in Norway and Finland
}

\author{
ALFRED GRANMO, OLA SKIFTE and ARNE C. NILSSEN
}

\begin{abstract}
GRANMO, A., SKIFTE, O. \& NILSSEN, A.C. 1982: Ptychoverpa bohemica (Pezizales) in Norway and Finland. - Karstenia 22: 43-48.

Ptychoverpa bohemica (Krombh.) Boud. (Pezizales: Morchellaceae) is recorded as new to Norway from two localities in the north of the country (Nordland and Troms counties). Several additional localities are also reported for Finland. The interpretation of some anatomical details and the ecology of the species are discussed.
\end{abstract}

Alfred Granmo, Ola Skifte \& Arne C. Nilssen, Tromso Museum/IMV, University of Tromse, N-9000 Tromsø, Norway

\section{Introduction}

In July 1981 one of us (A.C.N.) discovered a strange morel in the upper part of the valley Signaldalen in Troms, North Norway. This proved to be Ptychoverpa bohemica, in Europe mainly confined to the central parts of the continent. The locality was visited again a week later and an analysis of the vegetation at the site was made (Tab. 1). About 45 fruit bodies of the fungus were observed in an area of ca. $200 \mathrm{~m}^{2}$. Most of them were already overripe and had started to decay.

Later we were informed by Miss Åse Wormsen and Mr Trond Steen (in litt.) that they had found Ptychoverpa bohemica at Beiarn, Nordland, which thus becomes the second locality in Norway. Although we have no specimen from this site, the beautiful colour slides accompanying their letter are clearly of this species. They noticed the fungus for the first time at the end of May 1978, when five fruit bodies were seen. In May 1979 they observed hundreds of specimens in the same area (about $1000 \mathrm{~m}^{2}$ ), growing together with Verpa conica. The next year none of the species was seen. In 1981, on May 30th, they observed Ptychoverpa again (but no Verpa conica) in greater numbers than before.

\section{The Norwegian localities}

Troms. Storfjord: Signaldalen at the mouth of Parasdalen, $400 \mathrm{~m}$ W of farm Paras (UTM: DB 6467), alt. 100-110 m, 1.VII. 1981 Nilssen (TROM), 6.VII. 1981 Skifte (TROM, O). - Nordland. Beiarn: Strand, Moldjord (UTM: VQ 8831), alt. about $20 \mathrm{~m}, 1978,1979,1981$, Wormsen \& Steen (no specimens preserved).

The climate in the area of Signaldalen - Parasdalen is slightly continental. The mean annual precipitation is about $400 \mathrm{~mm}$ (Benum 1958). The temperature may be estimated from the measurements at the me- teorogical station of Skibotn (alt. $46 \mathrm{~m}$, at the Lyngen fjord). Adjustment for the difference in altitude gives an annual mean of $1.5^{\circ} \mathrm{C}$, and monthly means for January and February of $-5.5^{\circ} \mathrm{C}$ and $-6.2^{\circ} \mathrm{C}$, respectively. The corresponding values for the months May - August are $4.2^{\circ}, 8.9^{\circ}, 13.3^{\circ}$ and $12.2^{\circ} \mathrm{C}$.

The bedrock in this part of Troms consists of mica schists and marble of Cambro-Silurian origin.

Ptychoverpa was found in somewhat humid leaf mould, in a stand of Salix borealis interspersed with some young spruce (Picea abies). The influence of farming is evident: the site has been grazed and contains hemerophilic plants (cf. Tab. 1). The area is now cultivated but bears the remains of an earlier tall-herb - tall-fern birch forest.

The climate in Beiarn permits natural occurrences of the elm (Ulmus glabra), though the conditions probably vary greatly with the very varied topography. At the meteorological station of Beiarn, about $10 \mathrm{~km}$ west of Strand, the mean annual precipitation is 1170 $\mathrm{mm}$. It may be considerably less at Strand which is situated more to the northeast of, and in the rain shadow of, the high mountains and glaciers nearer the coast. At Strand the specimens were found on fluvial deposits of sand and silt in a mixed alder ( $A l$ nus incana) - willow forest.

Ptychoverpa bohemica (Krombh.) Boud.
Morchella bohemica Krombh.
Verpa bohemica (Krombh.) Schroet.
Morchella bispora Sorok. (fide Imai 1954).

The gross morphology is satisfactorily described by i.a. Seaver (1942) and Wells \& Kempton (1967). Only microscopic observations of fresh material made in water medium will be mentioned here. 


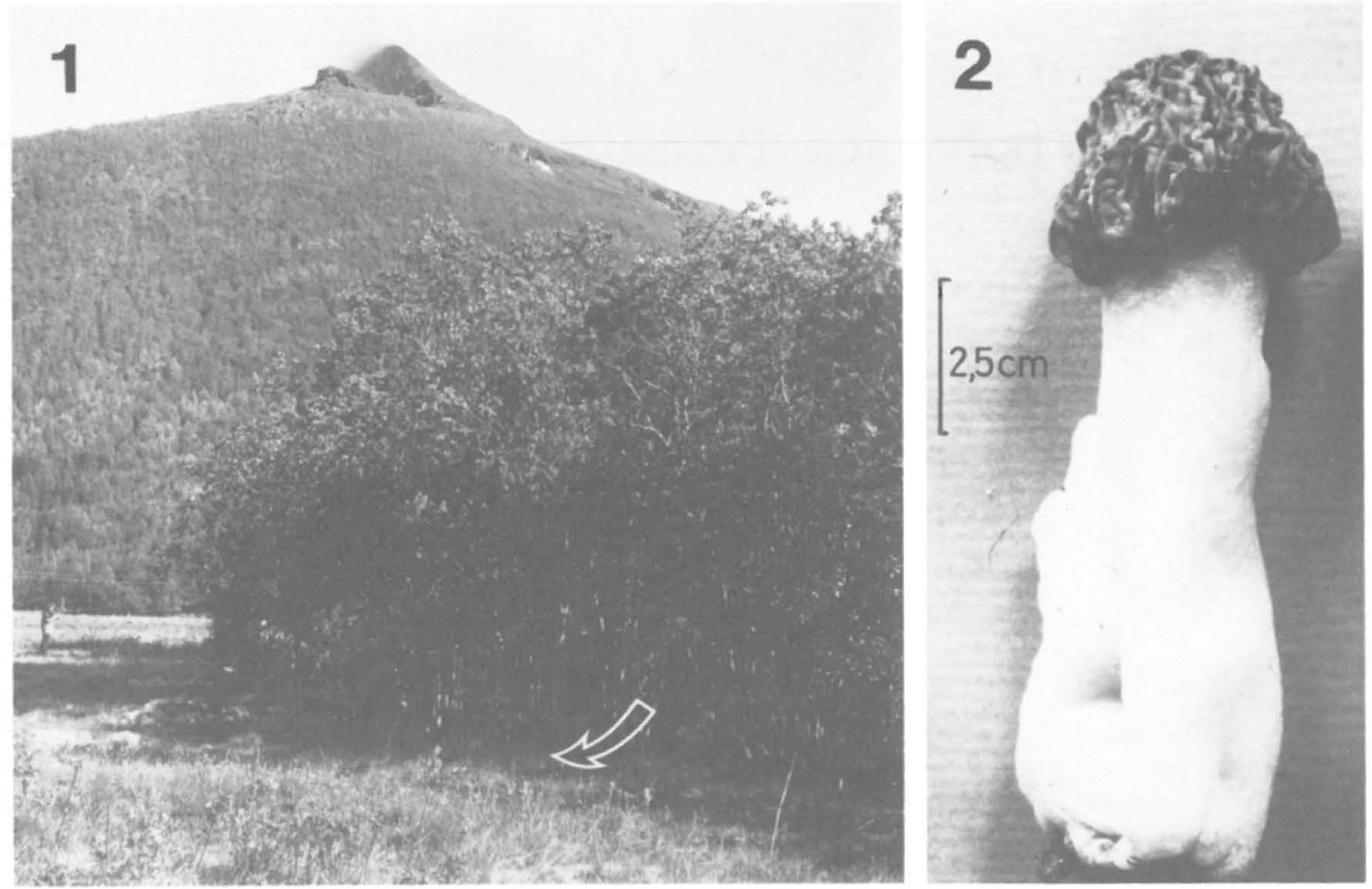

Figs. 1-3: Ptychoverpa bohemica. - 1: The locality in Signaldalen. Mount Paras (alt. $1419 \mathrm{~m}$ ) in the background. - 2: Specimen from Signaldalen (Photo V. Johansen). - 3: Specimens at Strand, Beiarn (Photo T. Steeen \& $\AA$. Wormsen).

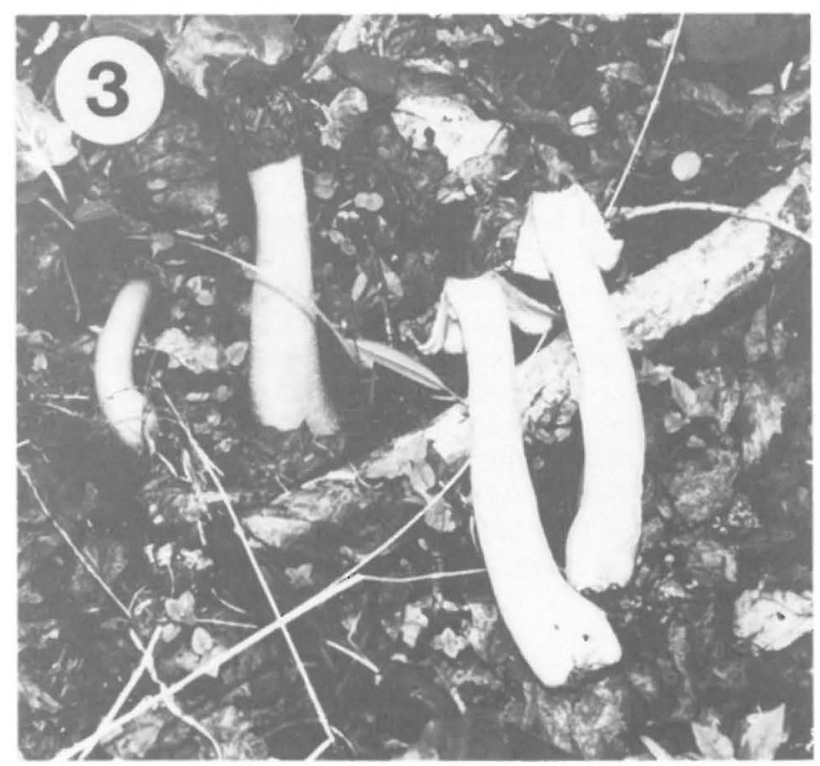

Asci cylindrical, operculate, 305-385 × 18-22 (-24) $\mu \mathrm{m}$, mean $344 \times 21 \mu \mathrm{m}, \mathrm{J}-$, 2-spored, seldom 3 -spored. Paraphyses slightly clavate at apex (up to $12 \mu \mathrm{m}$ ), branched or not, septate; contents pale yellow to brown yellow, walls thick, brown, septa strong and distinct. Spores (52-) 55-86 $\times 17-23 \mu \mathrm{m}$, mean $66 \times 19 \mu \mathrm{m}$, pale yellow to hyaline, ellipsoid to navicular with obtuse or slightly acute ends, often with small bubbles at the ends, dextrinoid and cyanophilic. In overripe material the paraphyses and spores are filled with yellow bubbles or granules.

Anatomy of pileus (radial section): Hypothecium small-celled, 56-80 $\mu \mathrm{m}$ thick, medullary excipulum two-layered, forming a textura porrecta in its upper 


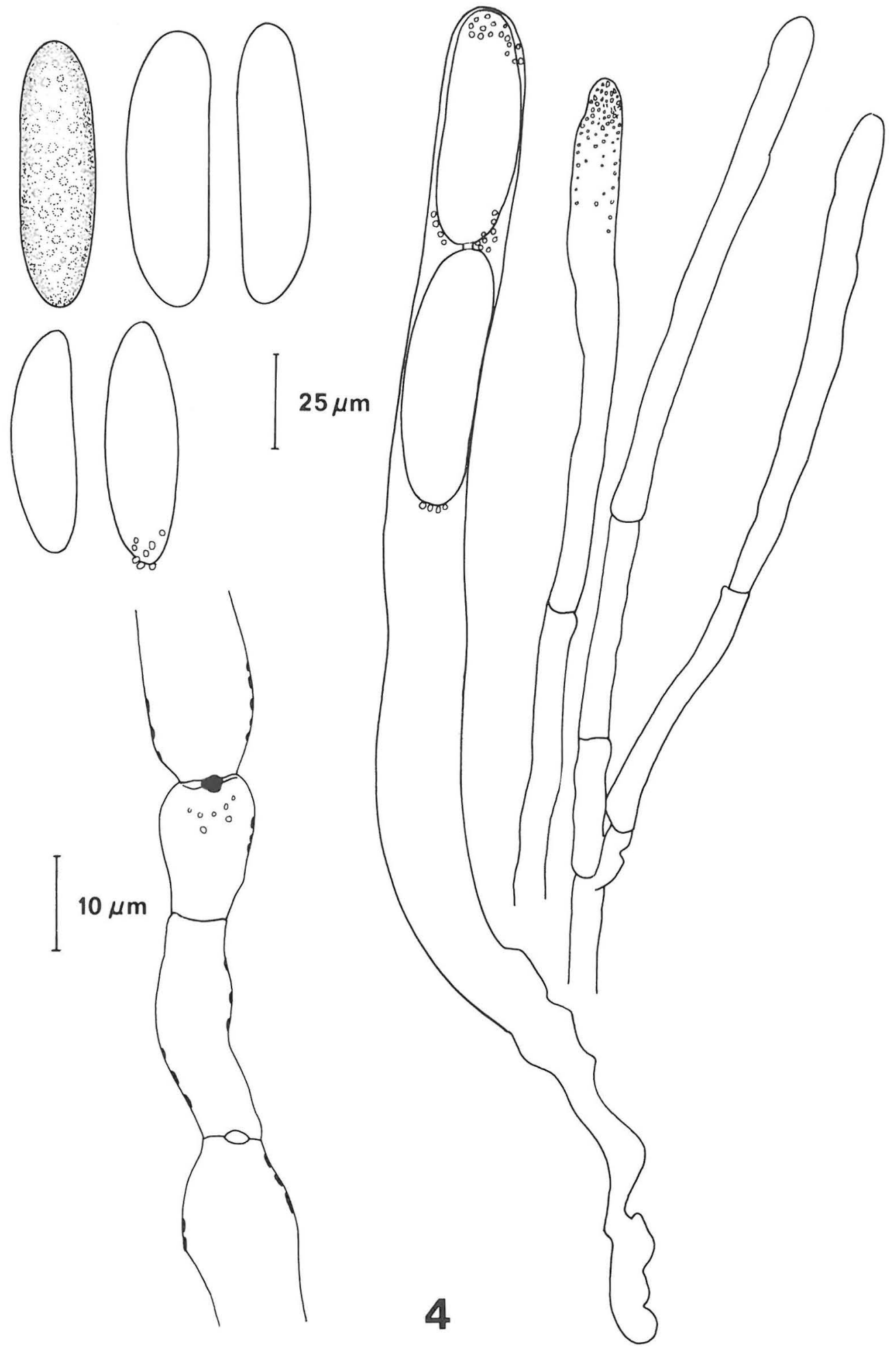

Fig. 4: Ptychoverpa bohemica. Spores, ascus, paraphyses. Detail of hypha in the textura porrecta layer. All in water mounts. 
Tab. 1. Analyses of the plant community with Ptychoverpa bohemica in the Signaldalen valley, Storfjord. Cover degrees according to the Hult-SernanderDu Rietz scale.

$\mathrm{K}=$ Constancy $(\%), \mathrm{D}=$ Mean cover of 5 analyses. Sample area: $1 \mathrm{~m}^{2}$. Altitude: $100 \mathrm{~m}$.

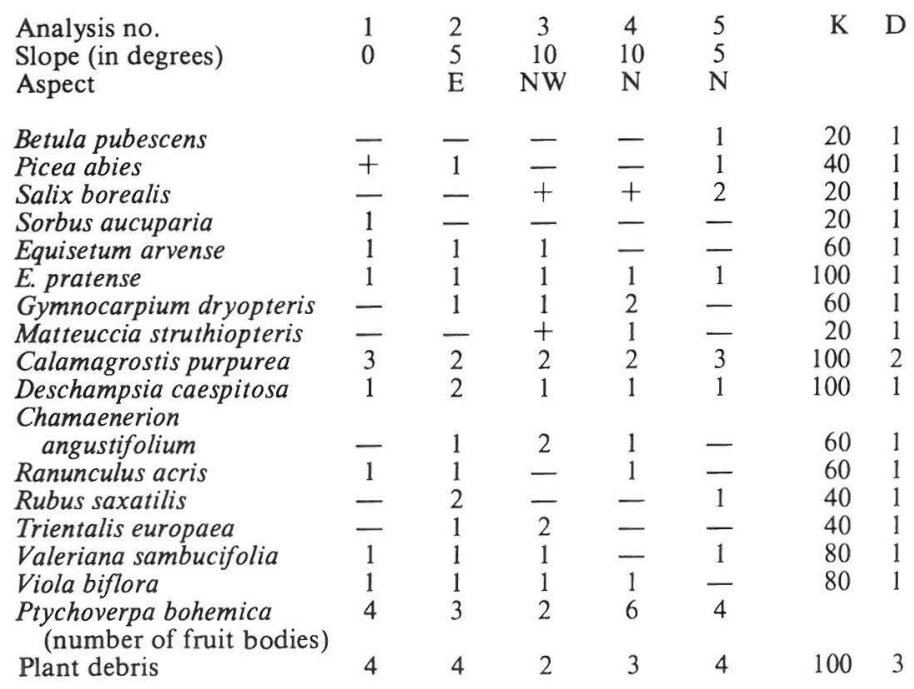

Additional species which occurred in the area analysed: Achillea millefolium, Corallorhiza trifida, Equisetum palustre, Festuca rubra, Melandrium rubrum, $\mathrm{Pa}$ ris quadrifolia, Rumex acetosa, Stellaria cf. longifolia, Thelyperis phegopteris and Urtica dioica.

part, $150-240 \mu \mathrm{m}$ thick, with inflated cells with incrusted walls, 30-50 $\mu \mathrm{m}$ long and 7-17 $\mu \mathrm{m}$ wide; then follows a fairly loose textura intricata, about 200 $\mu \mathrm{m}$ thick. Ectal excipulum a tough textura intricata, about $200 \mu \mathrm{m}$ thick (difficult to cut!), covered with a thin, white, loose hyphal mat, which in ripe specimens either is seen as small, pale hyphal tufts on the underside of the cap, or merges completely with the underlying yellowish tissue.

Material moderately heated in lactophenol cotton blue showed conspicuous Woronin bodies at the septa, especially at the septa of the paraphyses and in the textura porrecta layer.

Comments on anatomy: The description of the excipular layers deviates somewhat from that of Wells \& Kempton (1967). These authors observed what was more or less textura intricata in both medullary and ectal excipulum which is thus more similar to that of Verpa conica (cf. Eckblad 1968). The disagreement may be explained by the fact that Wells and Kempton examined dried herbarium material. Further, the tissue of this species apparently contains abundant fatty substances, or oils. These are undoubtedly the cause of the curious way in which the fruit bodies first 'melt' before the process of drying can continue. Once dried, it was not possible, by any means, to restore the pileus tissue to its original structure.
It should be mentioned that despite its delicate taste, Wells \& Kempton (1967) reported cases of iilness after ingestion of this fungus.

\section{Habitat and distribution}

Lange (1974) describes Ptychoverpa as having a southeastern distribution in Europe, the species being confined to the continental parts of the nemoral region, and being totally absent from the northwestern parts. In the Nordic countries it has been reported around Stockholm in Sweden, and in southern Finland. In Finland it was later recorded as far north as the Kemi area near the head of the Gulf of Bothnia (Ulvinen 1976:295), and several new Finnish localities have been added here to our map.

Outside Europe, Saccardo (1889) lists it from Kashmir and the Kazan region in the U.S.S.R. Imai (1954) mentions it from Sapporo, Japan. Seaver (1942) records it from New York to Minnesota and Oregon in the United States, and Wells \& Kempton (1967) found it in southern central Alaska, though not as a common fungus.

Few habitat descriptions for Ptychoverpa are known to us. Imai (1954) writes merely: 'Habit. in pratis et in herbosis silvatis, vere'. Wells \& Kempton (1967) found Ptychoverpa in leaf mould under cot- 


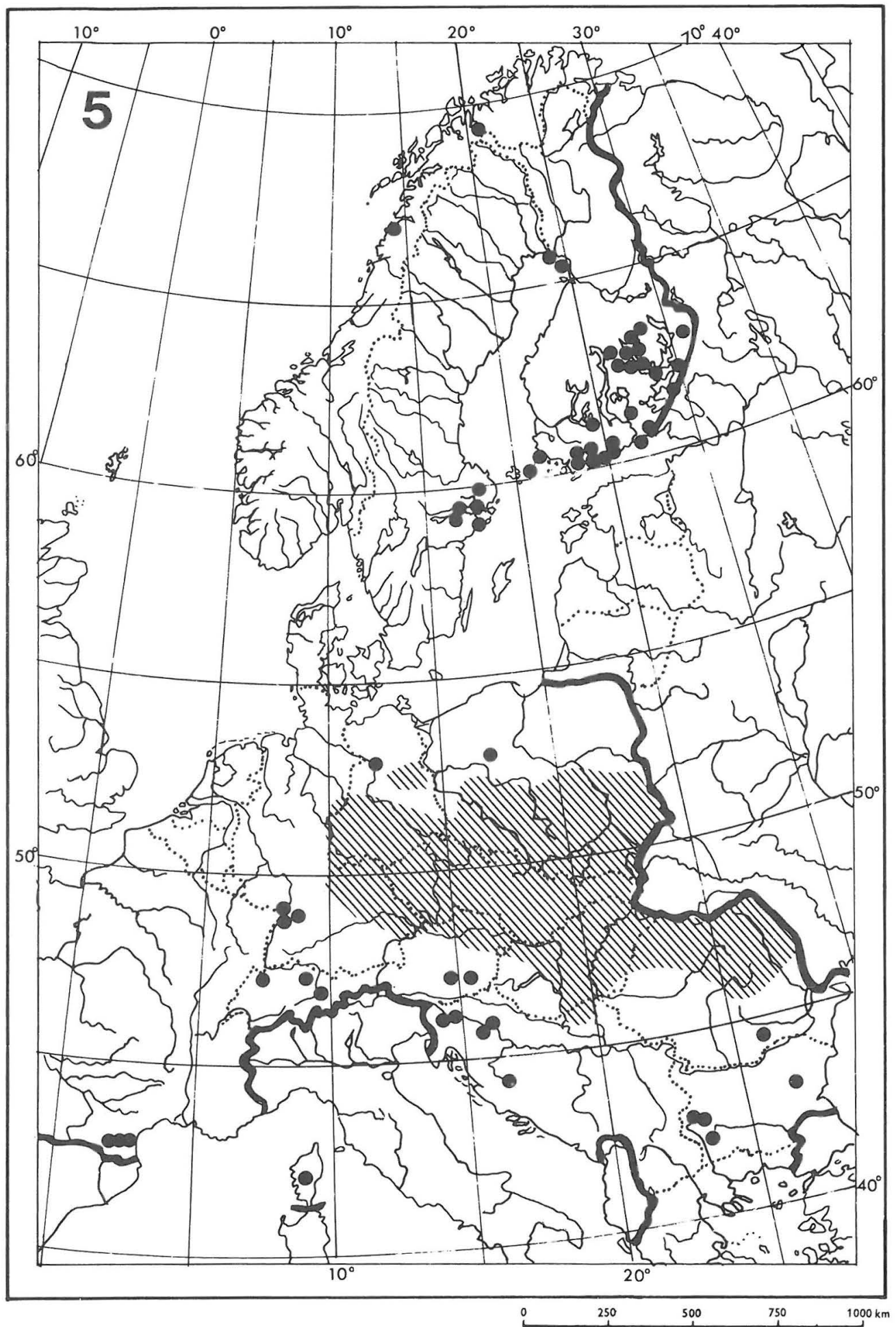

Fig. 5: The distribution of Ptychoverpa bohemica in Western Europe. Based on the maps of Lange (1974) and Ulvinen (1976). 
tonwood (Populus balsamifera) and alder (May-June) in Alaska, and stated that it was generally found on old glacial moraines which had a shallow covering of leaf mould. Michael \& Hennig (1971) record it from light deciduous woods and gardens, frequently near poplars and willows. Finally, Breitenbach \& Kränzlin (1981) report it from the Swiss Alps (1000 m alt.) 'an humosem Bachgraben unter Gebüsch' (at the end of May). These observations are at least not contradictory to those made at the Norwegian sites.

If this species really does prefer a somewhat continental climate as indicated by Lange (1974), then its apparent absence from northwestern Europe is to be expected. However, in a country like Norway, with its immense variations in topography, suitable habitats for a fungus with continental preferences may occur even in geographical areas considered to be relatively humid. To decide whether the species really has such climatic requirements, we should consider the climate of the actual site of the fungus, rather than the general climate of a larger region. The habitats recorded so far give the impression of a species distributed in subhumid or fairly continental localities, primarily in areas associated with hardwoods in the northern temperate zone.

List of new Finnish localities (kindly sent us by T.Ahti): Aland (Ahvenanmaa). Kumlinge: Snäckö, 1.VI.1980 Strandberg $2182(\mathrm{H})$. - Varsinais-Suomi. Kustavi: Pohjois-Vartsala, Virtholma, 16.V.1976 Hallberg (TUR). - Uusimaa. Kirkkonummi: Evitskog, 24.V.1980 Saarenoksa (H, OULU). Lohja: Paloniemi, 8.V.1977 Korhonen 1653 (H). Nurmijärvi:
Ojakkala, 19.V.1977 Askola 316 (H). Sipoo: Hindsby, 18.V.1979 Korhonen \& Saarenoksa (H). - Etelä-Karjala. Virolahti: Ala-Säkäjärvi, 20.V.1967 Rintanen (TUR). - EteläHäme. Heinola: Jyränkö, 1.VI.1980 Heino (H). - PohjoisSavo. Kangaslampi: Viljolahti, 7.VI.1981 Siltanen (KUO).

Acknowledgements. We wish to thank Astha Skifte for help during the field work, Ellen Beck for the drawings, and Rob Barret for improving the language. For information about the new Finnish localities we are grateful to Mauri Korhonen, Teuvo Ahti, Yrjö Mäkinen, Tauno Ulvinen, Heli Heikkilä and Harri Harmaja.

The Norwegian Research Council for Science and the Humanities has given financial support to the investigation.

\section{References}

Benum, P. 1958: The flora of Troms fylke. - Tromsø Mus. Skr. 6: 1-402.

Breitenbach, J. \& Kränzlin, F. 1981: Pilze der Schweiz 1. Ascomyceten. - 313 pp. Luzern.

Eckblad, F.-E. 1968: The genera of the operculate Discomycetes. - Nytt Mag. Bot. 15: 1-191.

Imai, S. 1954: Elvellaceae Japoniae. - Sci. Rep. Yokohama Nat. Univ. (Sect. 2) 3: 1-35.

Lange, L. 1974: The distribution of Macromycetes in Europe. - Dansk Bot. Ark. 30 (1): 1-105.

Michael, E. \& Hennig, B. 1971: Handbuch für Pilzfreunde 2. $-467 \mathrm{pp}$. Jena.

Saccardo, P.A. 1889: Sylloge fungorum omnium hucusque cognitorum 8. - 1143 pp. Padua.

Seaver, F.J. 1942: The North American cup-fungi (Operculates). Suppl. ed. - 371 pp. New York.

Ulvinen, T. (ed.) 1976: Suursieniopas. - 359 pp. Helsinki.

Wells, V.L. \& Kempton, P.E. 1967: Studies on the fleshy fungi of Alaska 1. - Lloydia 30: 258-268.

Accepted for publication

on December 11, 1981 